\title{
Pandemic (H1N1) 2009 lives in some people for at least eight days after symptoms develop
}

$\mathrm{T}$ he pandemic (H1N1) 2009 virus remains alive on the eighth day in $8 \%-13 \%$ of people after they develop flu symptoms, a team of Quebec researchers has determined.

Dr. Guy Boivin of the Centre Hospitalier Universitaire de Quebec and Dr. Gaston De Serres of Quebec's Public Health Institute tested members of 65 families in Quebec who contracted the virus from May through July. Their findings, part of a larger study looking at whether asymptomatic people have pandemic (H1N1) 2009, are intended to guide public health officials who are trying to reduce the spread of the virus.

De Serres and Boivin tested 173 people enrolled in the study 8 days and 10 days after they first presented with symptoms. On day 10 , they were not detecting live virus in any of the 43 laboratory-confirmed cases of people with the virus.

The results of the study indicate that a large number of people with pandemic (H1N1) 2009 are still contagious after their fever breaks, and at least a proportion of people with the virus may be able to transmit it to others for a day or two longer than those who have seasonal influenza, De Serres says.

"For seasonal influenza, in general, we consider that within seven days, the shedding of the virus should be over," he says. "With this virus, we see that yes, the shedding of the virus is over for the majority of the people, but there are still people who are potentially contagious on day 8."

In general, public health authorities advise people with seasonal influenza to wait for 24 hours after their fever has broken before returning to work or school. Currently, that is the advice the

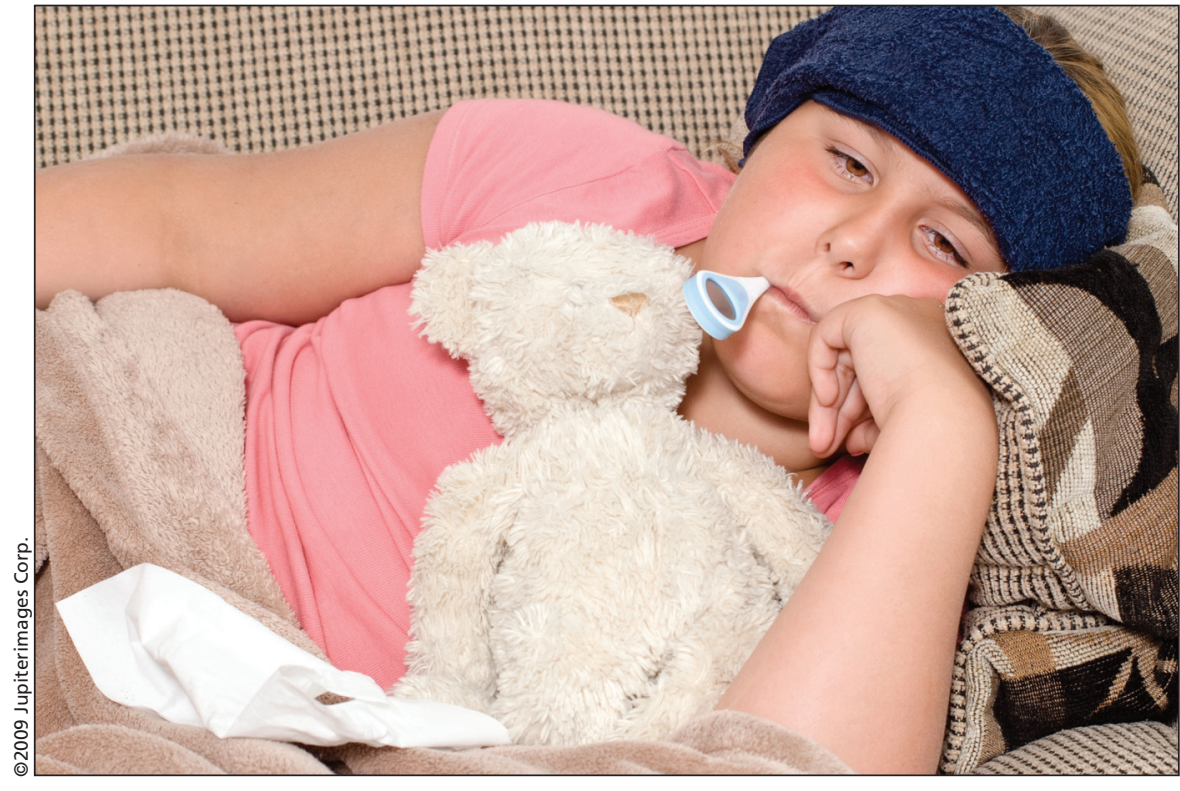

Public health authorities typically advise people to wait 24 hours after their fever has broken before returning to work or school, but a new study suggests that the pandemic (H1N1) 2009 virus may be contagious for longer periods.

US Centers for Disease Control offers on its website to people with pandemic (H1N1) 2009.

But that period of voluntary isolation is not likely to be effective in reducing transmission among at least a segment of those with the virus, says De Serres. "If on day 8 , we still have $8 \%-13 \%$ of people having live virus, to go back after two, three or four days (of presenting symptoms) is really too soon.'”

Public health officials should advise people how long to stay home, but will have to balance their advice given the societal effects of having large proportions of the population off work and off school if there is an extensive outbreak, De Serres says.
Currently, the Public Health Agency of Canada is advising people who have pandemic H1N1 (2009) to stay home until they are better.

De Serres says people working with vulnerable populations, such as health care workers caring for newborns, need to stay home until the risk of transmission is past. He adds that other members of the general public need to consider whether they are still coughing and sneezing and could spread the virus easily.

De Serres and Boivin presented their findings at the Inter-Science Conference on Microbial Agents and Chemotherapy in San Francisco on Sept. 15. - Laura Eggertson, Ottawa, Ont.

DOI:10.1503/cmaj.109-3062 